\title{
The Laghu-Yoga-Vāsiștha and Its Persian Translation
}

This chapter will introduce the contexts and content of the Sanskrit treatise that forms the backbone of this study, the Laghu-Yoga-Väsistha, alongside its early Persian translation, the Jūg Bāsisht. The original Sanskrit treatise comprises a series of philosophical narratives that cumulatively articulate a brand of esoteric knowledge meant to liberate an aspirant from the phenomenal world, while nevertheless encouraging that aspirant to eschew the option of ascetic renunciation (samnyāsa) in favor of a continued, duty-bound existence within the context of society and householder and family life. Over the course of the early modern period, the Laghu-Yoga-Vāsiștha had become increasingly popular throughout South Asia across a surprising array of Hindu sectarian and linguistic boundaries, and the Mughal court too can be counted among the treatise's captivated audiences. Among the multiple translations of the Laghu-Yoga-Väsiștha patronized by the Mughal court, the Persian Jüg Bāsisht was the earliest to be composed, commissioned by the soon-to-be emperor Jahāngīr (r. 1605-27) and completed by the translation team of Jagannātha Miśra Banārasī, Pațhān Miśra Jājīpūrī, and Niẓām al-Dīn Pānipatī in the year 1597.

This chapter will first briefly sketch the history and origins of the Laghu-YogaVâsiștha as well as the text's basic narrative and philosophical content. So as to set up the line of metaphysical inquiry that will thread throughout this study, I will then contextualize and outline some of the Laghu's foundational metaphysical terms, concepts, and teachings. My overarching objective is to attempt to retrace the intellectual processes by which the translation team of Jagannātha Miśra, Paṭhān Miśra, and Pānīpatī creatively translated these very same metaphysical notions into an Islamic Arabo-Persian philosophical lexicon. Accordingly, this 
chapter then turns to a brief overview of the Mughal court's translation enterprise and an introduction to our three intrepid translators. As will be seen, however, precious little can be recovered regarding the biographies of the translation team members, thus prompting the broader methodology for the study of the Jug Bāsisht that characterizes this book, as outlined in the introduction. Finally, this chapter concludes with a somewhat more immediate "taste" of the treatise via a sample narrative from the Sanskrit Laghu-Yoga-Väsiștha, translated alongside its Persian rendition in the Jüg Bāsisht.

\section{INTRODUCING THE SANSKRIT TREATISE}

The Sanskrit Laghu-Yoga-Väsiștha (hereafter "Laghu") was composed by the Kashmiri pandit Gauḍa Abhinanda-of probable Bengali ancestry, based upon his name-likely in the tenth century, though possibly as late as the mid-thirteenth. There has long been considerable disagreement over the dating of the Laghu, stemming not only from the pervasive difficulty of establishing absolute dates for Sanskrit materials, but even from an inability to identify which historical "Abhinanda" the author might in fact be. The Abhinanda who authored the Ramacarita seems to be the generally favored option, although another Abhinanda, son of the famous poet and Nyāya-philosopher Jayanta Bhatța, stands as another possibility, while an otherwise unknown third Abhinanda also cannot be ruled out. ${ }^{1}$ It is further worthy of note that the Laghu-Yoga-Väsiștha itself represents only one node of an especially complicated textual history. The Laghu's origins lie in a tenth-century Kashmiri treatise known as the Mokșopayya. ${ }^{2}$ This core Moksopāya text was then modified in succeeding centuries, with additional textual layers and frame stories affixed to it, gradually altering the treatise's contents in significant ways-most characteristically, domesticating it within a Brahminical or Vedāntic framework while excising several Buddhist features. ${ }^{3}$ Although diverse versions, redactions, and recensions abound, rendering any brief statement on the topic decidedly incomplete, it can generally be said that the roughly thirty-thousand-verse Mokssopayya was first abridged and reworked in the form of the Laghu ("short") Yoga-Vāsiștha, approximately five to six thousand verses in length; ${ }^{4}$ a third, distinguishable treatise subsequently appeared, commonly known as the "Yoga-Vāsiștha," roughly comparable in length to the Mokșopāya but in fact a redaction presupposing both the Mokssopaya and the Laghu and synthesizing verses, sections, and fragments from the two texts. ${ }^{5}$

This Laghu-Yoga-Vāsiștha, consisting of six books (prakaranas) and written in an accessible narrative style resembling the Sanskrit epics or Purānas, tells the tale of the young prince Rāma, identified with the famous Hindu hero of the Rāmāyana. Rāma, afflicted with vairāgya (dispassion) towards the affairs and things of the world, has lost all taste for kingship and royal duties, much to the dismay of his 
father Daśaratha. Eventually, Rāma is led to engage in a lengthy spiritual dialogue with the renowned sage ( $r s ̦ i$ ) Vasiștha in an attempt to address the former's mounting despair. After leading Rāma, by means of numerous parables and didactic discussions, through successive levels of instruction in eschewing the ego (ahamkiāra) in pursuit of supreme knowledge (jñāna), Vasișțha eventually guides Rāma to a state of liberation (mokșa). However, Vasiștha further convinces Rāma that, rather than withdrawing from the world in the manner of a renunciant ascetic, Rāma should instead return to his worldly royal duties, but remain all the while detached and rooted within this supreme knowledge that grants ultimate liberation from the phenomenal world, even while one still continues to live one's life within the world (a condition known as jivanmukti, "liberation while living"). Within each of the Laghu's six books, Vasișțha offers Rāma a series of scaffolded teachings, delivered via direct instruction, with each teaching immediately followed by a short tale or allegory that illustrates the teaching narratively. These narratives are populated by a wide cast of characters drawn from the copious storehouses of Sanskrit myth, literature, folktale, and scripture.

The Laghu-Yoga-Väsistha is a far-ranging and multifaceted text to which this study can hardly begin to do justice. Within this treatise, Abhinanda engages a broad array of philosophically fertile topics, ranging from the diaphanous relationship between dream and reality, the nature of time and space, and questions of fate, chance, and free will, to varied and potent reflections upon ethics, virtue, desire, self-discipline, and the very reality of consciousness itself. The treatise's literary and aesthetic features are equally fascinating; Vasiṣtha’s narratives "work on" both Rāma and the reader in ways meant to provoke particular affective responses, realizations, and sudden shifts of consciousness and frames of reference. Constantly probing the evanescent line between imagination and reality, the treatise aims to show as much as to tell the profound, oft-unrecognized extents to which the character of life and the world-its joys along with its sorrows; its pleasures and its tribulations-indeed depends upon our own construal, perception, and mental construction of it. Much as in a dream, in "waking life" too we are both the (typically unknowing) creator as well as the participant ensnared within our own imagined worlds, confronted by the urgent and daunting task of waking up when we likely are not even aware that we are asleep. ${ }^{6}$ As Wendy Doniger has delightfully described the work, "[i]t is as if someone took the abstract concept 'The universe is illusory' and made it somehow anthropomorphic, producing a kind of teaching device to make us understand what it feels like to realize that everything is an illusion." ${ }^{\text {To }}$ my great regret, such potent, affective, even existential dimensions of the Laghu-Yoga-Vāsistha, unfortunately but unavoidably, lie beyond the scope of this study, while, on the philosophical front, the demands of space and practicality compel me to single out only a few manageable issues. As such, and taking the lead from a number of the Persian materials relevant to the inquiry, this study proposes to focus primarily on the metaphysics of the 
Laghu-Yoga-Vāsistha, with a full awareness of all that gets lost in delimiting the scope of the work thus.

Although many modern scholars, especially Mughal specialists less acquainted with Sanskrit thought, often refer to the Laghu as a treatise of "Advaita Vedānta," the text is not at all a seamless fit with this descriptor. While the text undeniably affirms a "non-dual" (the literal meaning of the term "advaita") metaphysics, the Sanskrit intellectual tradition is witness to several competing varieties of nondualism, of which Advaita Vedānta is only one. The earliest and arguably most fundamental layers of the Laghu, meanwhile, hail from an alternate provenance, namely, the Kashmiri milieu that gave rise to the original iteration of the text, the Moksopayya. As such, a number of the Laghu's most basic metaphysical terms and teachings rub against the grain of "mainstream" Advaita Vedānta, while it would take several more centuries before the Yoga-Vāsiștha would become a text broadly accepted by Advaita Vedāntins. This absorption of the Yoga-Vāsiștha into the Advaita Vedānta "canon" was accomplished through successive alterations that were introduced into the Mokșopāya text over several centuries, ultimately rendering it into the more "Vedānta-friendly" Yoga-Vāsiṣtha and Laghu-Yoga-Vāsiṣtha versions well-known today. ${ }^{8}$ Indeed, the original Mokșopāya in many ways railed against the sort of "Brahminical orthodoxy" typically associated with Advaita Vedānta, the early, more "maverick" iterations of the work affirming liberation as available to anyone-even children and those without access to the śästrasprovided that one only engage in the proper practice of "rational reflection" or "inquiry" (vicāra), depicted as a kind of "yoga." By the time the text had morphed into the Laghu-Yoga-Väsiștha known to the Mughal court, however, this tone had been noticeably altered, replaced by a more ambivalent stance wherein certain śāstras are praised for facilitating liberation while others are criticized for only increasing attachment and bondage to the world. This domestication of the work to Advaita Vedānta was further accomplished through the exegetical efforts of such important later Advaitins as Vidyāraṇya (d. 1386), Prakāśānanda (ca. 1500), Appayya Dỉkșita (d. 1592), and, of course, Madhusūdana Sarasvatī, who will be examined in the next chapter. ${ }^{9}$ Indeed, by Madhusūdana's time, it appears the text's authority was well-established and seemingly uncontroversial: in the wake of Vidyāranya's efforts, for at least a significant enough body of Advaitins, the teachings of the Laghu-Yoga-Vāsiștha were widely deemed to be fully consonant with the scholastic Advaita Vedānta tradition that traces its roots back to the founderfigure of Sañkarācārya $\left(8^{\text {th }}-9^{\text {th }}\right.$ c. $)$, such that Madhusūdana did not need to justify resorting to it as an authoritative text.

Despite this late, eventual embrace of the Laghu-Yoga-Vāsiștha on the part of Advaita Vedānta, the two traditions' respective metaphysics present certain clear discrepancies, the harmonization of which is not at all obvious from the outset. Let us take, by way of illustration, one representative, metaphysically-oriented passage from the Sanskrit Laghu: 
When, just as the wind enacts the pulsating power of vibration (spanda-śakti), the self (ätman), entirely on its own, suddenly enacts a power (śakti) called "desire/imagination" (samkalpa), then [this] self of the world, making itself as if in the form of a discrete semblance ( $\bar{a} b h \bar{a} s a)$ that abounds in the drive toward desire/imagination (samkalpa), becomes mind (manas). This world, which is just pure desire/imagination (samkalpa-mātra), enjoying the condition of being seen (drśya), is neither real (satyam) nor false (mithyā), occurring like the snare of a dream. ${ }^{10}$

This passage contains a number of the Laghu-Yoga-Vāsiștha's most characteristic metaphysical terms and concepts. ${ }^{11}$ Distinct from Advaita Vedānta, the Laghu erects a metaphysics that is very much its own, not reducible to any one tradition or extant philosophical school. It exhibits an evident philosophical kinship with the non-dualist Śaiva traditions that originally emerged from the same Kashmiri milieu, including the "Spanda," "Trika," and other schools perhaps most famously associated with the figure of Abhinavagupta (d. 1016). ${ }^{12}$ It would be simply inaccurate, however, to call the Laghu a "Kashmir Śaiva/Trika text," despite the shared, general Kashmiri non-dualist milieu from which both the Laghu/Mokșopayya and the Kashmiri Śaiva traditions hail. ${ }^{13}$ Whereas Advaita Vedānta steadfastly endeavors to maintain a conception of the ultimate Reality/Self (brahman/ätman) that is devoid of all change and activity, the non-dualist Kashmir Saivas, in sharp contrast, wholeheartedly embrace a dynamic, active conception of the Self/absolutely Real. Abhinanda's metaphysics resonates with the latter, as, in the passage above, we observe him attributing to àtman a "power" (śakti) of "pulsation" or "vibration" (spanda), characterizations of the ultimate Reality largely foreign to classical Advaita Vedānta but central to the Kashmir Śaiva systems, the latter of which label this ultimate Reality "Śiva” or "cit" (pure consciousness). As Dyczkowski articulates this "doctrine of vibration" within the context of non-dualist Saiva thought: "[e]very activity in the universe, as well as every perception, notion, sensation or emotion in the microcosm, ebbs and flows as part of the universal rhythm of the one reality ... Spanda [is] the dynamic, recurrent and creative activity of the absolute." ${ }^{14}$ Hence, for these Saivas of Kashmir, and also for Abhinanda, the entire universe, with all its entities, objects, and events, are vibrations and modifications of a dynamic, infinite, pulsating pure consciousness (variously termed cit, caitanya, samvid, and so on).

Alongside these features of an undeniably Kashmiri Saiva provenance, other features of the metaphysics articulated in this passage form a potential bridge with Advaita Vedānta. Abhinanda affirms here, for instance, that the pure Self/ consciousness undergoes the appearance ( $\bar{a} b h \bar{a} s a)$ of a transformation but without enduring any real transformation, as the power of àtman's pulsation (spanda) makes it manifest itself "as if" in a new form or appearance, namely, the objects of the phenomenal world. Now, ābhāsa is a term deployed by both non-dualist Kashmiri Saivas as well as Advaitins, in addition to several other Sanskritic traditions: the Buddhist Yogācāra (and, to a lesser extent, Madhyamaka) schools were perhaps 
the first to develop the concept in detail, emphasizing the ābhassas of the world as, in fact, false appearances, constructed by the mind (citta), which endows them with the semblance of objective substantiality, when in actuality such objects are only "empty" (śünya) or "mind-only" (citta-mätra). ${ }^{15}$ There can be little doubt that these early Buddhist valences of the term ābhāsa persist within the Yoga-Vāsiștha literature, which never tires of emphatically affirming the phenomenal world as the construction of our own minds (manas, citta) and our cognitive imaginings (kalpa, samkalpa, vikalpa); indeed, the text explicitly echoes the Buddhist vocabulary of the world as "mind-only" (manomātra, citta-mātra,) on repeated occasions. For instance: "whatever arises is [just] the mind, like a city in the clouds. ${ }^{16}$ All this that appears, a self-expansion called 'the world' (jagat), is no more than error (bhrānti);" "17 "this world entire is mind-only (manomätra) . . the mind is the sky, the earth, the wind. Indeed, the mind is great;" 18 "all this is the mind (manas) which flashes forth (sphurati) within [its] creations (srști)." ${ }^{19}$

Similarly, the Advaita Vedānta deployment of ābhāsa, as will be seen in greater detail in the next chapter, likewise emphasizes the "appearance" of the world as, indeed, the false appearance (bhrānti) of an imagined world, the product of ignorance (avidyā) which possesses no substantial reality of its own. Perhaps the central difference between Buddhist vs. Advaitin usages of the term, however, is that, while Buddhist invocations of ābhāsa are primarily intended to provoke a recognition of the ephemeral and mind-dependent nature of phenomenal objects, Advaita adds something further to the account: once phenomenal semblances are recognized as illusory, the ground is cleared for the recognition of an additional entity that is ultimately real, "hiding behind" those false appearances the entire time, namely, the pure Self (ätman) or absolute Reality (brahman). ${ }^{20}$ At times, the Laghu too inhabits a similar mode, sweeping away the transient and ephemeral to leave only the absolute as remainder, for instance: "all these movable and unmovable things of the world ... are destroyed as a dream is destroyed in deep, dreamless sleep (susupti). Then, a certain being remains that is still, deep, neither light nor darkness, all-pervasive, unmanifest, without name. For the practical purposes of speech (vyavahārārtham), the name of that exalted self (ātman) is imagined by the wise to be 'truth/cosmic order' (rta), 'ätman,' 'the Highest,' 'brahman,' 'reality' (satyam), and so forth." ${ }^{21}$

And so, for Advaita Vedānta, the "semblances" (ābhāsas) that constitute the objects of the phenomenal world are at best merely conventionally real (vyāvahārika), but not ultimately so (pāramārthika), ätman being the sole ultimate Reality; in several moments, the Laghu is happy to more or less echo this account. Furthermore, as will be seen in greater detail in the next chapter, Advaita Vedānta's insistence that the ultimate Reality/Self (brahman/ätman) is devoid of all change and transformation means that these false semblances of the world cannot be directly grounded in the changeless brahman, but rather, must be grounded in "ignorance" $($ avidyā). Now, ignorance is itself only tenuously connected with brahman, rather 
like light and shadow, light (brahman) being that which immediately destroys the shadow of ignorance upon contact. Hence, Advaitins predominantly depict the two as far more opposed than they are related; äbhāsas, accordingly, do not really "come from" brahman, on this account, but are instead instantiations and products of brahman's opposite, ignorance. For the non-dualist Kashmiri Saivas, in contrast, the notion of ābhāsa is deployed to notably divergent effect: with Kashmiri Saivas' embrace of an "infinite absolute that manifests itself actively through the finitude and transitoriness of phenomena perpetually changing in consonance with the absolute's activity" - that is, the "pulses" or "vibrations" (spanda) of pure Consciousness-the result is a conception of ābhāsa "not ... in the [Advaitin] sense of semblance, but as the manifest form of the absolute," in other words, less like the relationship between light and shadow, and more like the relationship between the sun and the various individual rays spreading forth from it. ${ }^{22}$ In this Kashmiri Saiva view, there is thus a much more pronounced ontological continuity-indeed, an identity-between appearance and Reality, an insight the Yoga-Väsiștha literature is all too happy to echo on repeated occasions: "He who regards the multitude of rays as being distinct from the sun, for him, that multitude is indeed as something other than the sun ... [but] he who regards the rays as being indistinct from the sun, for him, those rays are [the same as] the sun. He (i.e., the latter) is said to be devoid of doubt;" ${ }^{23}$ "just as fulsome multiplicity, spreading forth as waves and the like, appears on the fluctuating ocean without being distinct from it ... in just the same way, this fulsome, multitudinous [world] — which is consciousnessalone and indistinct from it-manifests upon the ocean of consciousness;" "24 "the world (jagat) is, indeed, brahman, in this way, all this [world] is known through the knowledge of reality (sattva)." ${ }^{25}$ The Laghu, accordingly, in some moments inhabits the Advaitin conception of $\bar{a} b h \bar{a} s a s$ as fleetingly unreal like an evanescent dream, and, at other moments, embodies a Kashmir Śaiva-like insistence on world-appearances as the revelatory epiphanies of pure consciousness.

Closely related to the foregoing is another concept prominently featured in the above-translated passage from the Laghu, namely, Abhinanda's repeated mentioning of atman's "samkalpa." This term has its origins in the ancient Vedic practice of formulating an "intention" or "determination" to perform a ritual sacrifice for some desired end, ${ }^{26}$ and then later captures an Upanișadic notion of "intentionality" or "intellection" more generally. ${ }^{27}$ Samkalpa develops by the medieval period into the more generic meanings of a "wish/desire" or "intention," on the one hand, or an instance of "thought," "mental construction," "conceptualization," or "imagination," on the other. In fact, samkalpa, along with other closely overlapping terms for "mental construction" and "imagination" (vikalpa, kalpanā, etc.), are among the most characteristic concepts strung throughout the Laghu-Yoga-Väsiștha, ${ }^{28}$ which depicts a cosmos comprehensively pervaded by imaginations compounded upon imaginations, each of them with the seeming capacity to generate entire worlds and vivid (dream-)realities. ${ }^{29}$ Indeed, the very fabric of the "appearances" 
(äbhäsas) that comprise the cosmos, it seems, is woven of samkalpa through and through: as the above passage from the Laghu, and myriad others, declare, "this world is nothing but samkalpa." ${ }^{30}$ Much if not most of the time, the Laghu develops this theme in ways that would be largely recognizable to the likes of Advaita Vedānta or Buddhist Madhyamaka or Yogācāra, as the treatise works to dramatically illustrate the fundamental ways that our experience of the world is filtered through our own individual samkalpas-our mental constructs, conceptions, aspirations, inclinations, attachments, aversions, intentions, desires, imaginings, etc.-indeed, filtered to such an extent that the world as we know it, that is, as it is present to our phenomenal cognition, is quite literally our own "imagination" and creation.

But to affirm that this whole world is only samkalpa is to go a step further, which the Laghu does in ways that arguably rub against the grain of Advaita Vedānta and the Buddhist Madhyamaka and Yogācāra traditions alike. As in the above passage and several others, the Laghu resorts to the phrase "ätman's samkalpa," suggesting a notion of a foundational ground of pure consciousness (cit, caitanya, samvid), the pure Self, whose own desires, volition, and imaginations provoke the world's appearance-samkalpa, thus, goes all the way down, from the most transient and fleeting of external phenomena to the very bedrock of the cosmos. Such a description is ill-fitted to classical Yogācāra and Madhyamaka molds, who, holding to the core teaching of non-selfhood (an-ätmatva), are reluctant to admit a self (ätman) as the ultimate ground of existence such that could be described as "pure" (śuddha), "infinite" (ananta), the "highest" (parama), or "brahman," terms with which the Laghu, in contrast, is fully at ease. Even when certain Yogācāra and Madhyamaka traditions do articulate an arguable candidate for a comparable ultimate ground (áśraya) of phenomenal existence, such as the notion of the "store consciousness" (älayavijñāna) ${ }^{31}$ - or even when, for that matter, exceptional texts such as the Mahäparinirvāna- or Śrimālādevī-sūtras exhibit an unusual Buddhist willingness to describe this ultimate ground, termed tathägatagarbha (Buddhanature), as, precisely, a "self" (ätman) ${ }^{32}$-nevertheless, none of these Buddhist accounts attribute the same sort of creative agency to this ground of being as does the Laghu: neither ālayavijñanna nor tathägatagarbha are ever characterized by the sort of "volition" and "desire" (samkalpa) as the Laghu's "ätman." Likewise, although Advaita Vedānta, like the Laghu, is eager to affirm ätman as the ultimate, foundational ground of all reality, the àtman of the Advaitins, unlike that of the Laghu, is passive, static, and entirely devoid of any quality remotely resembling the "desire" and "volition" encapsulated by the term samkalpa. Unsurprisingly, samkalpa is not a feature of Advaita accounts of absolute Reality (ātman/ brahman), for brahman, ever changeless and impassive, simply cannot desire anything, while the dynamic process of creation, as already mentioned, takes place effectively external to brahman within the domain and operations of brahman's opposite, ignorance (avidyā). 
Once again, accordingly, it is the non-dualist Kashmiri Saivas who most closely reflect this central feature of the Laghu's metaphysics. Within the Kashmir Saiva corpus, the samkalpa of Siva/pure consciousness (caitanya, samvid) is an oft-invoked concept through which to depict the manifestation of the entire cosmos as directed and impelled, solely and comprehensively, by Siva's divine will and intention. ${ }^{33}$ Indeed, in a manner reminiscent of the Laghu, these non-dualist Saiva accounts similarly emphasize samkalpa's all-pervasive operation and presence across the entire span of the cosmos, as in Rājanaka Rāma's Spandavivṛti commentary upon a foundational text of these traditions, the Spandakārikās: "Śiva ... is the Wheel of Energies consisting of the manifestations of the wonderfully diverse universe sketched out (in this way) by (his own) will alone (samkalpamātra)." ${ }^{4}$ The Laghu and non-dualist Śaiva traditions hence share a metaphysical vision of an infinite consciousness rendered overflowing with samkalpa. At some point, as an intrinsic capacity of itself, it begins to "imagine/conceive" and "desire/ intend" (samkalpa) all of the possible manifestations, modifications, and deployments of its own self. The ocean of consciousness, in other words, "becoming" 35 aware of the infinite śaktis ("powers," "potentialities," or "possibilities") contained within itself-like the ocean's power to become waves, foam, clouds, ice, etc.- and desiring or intending to manifest those possibilities, by means of its own inherent power of vibrant pulsation (spanda), actualizes those possibilities in the forms and appearances (ābhāsas) of the phenomenal world. ${ }^{36}$ Significantly for this study, for the Muslims involved in the Mughal translation movement, as will be discussed below, this particular Hindu account of the appearance of the phenomenal universe was considerably more compelling than, for instance, the accounts of classical Advaita Vedānta. A certain resonance between this Laghu/non-dualist Śaiva metaphysics, on the one hand, and the wujūdi metaphysics of Mughal Muslim thinkers, on the other, may help to explain, in part, the great popularity that the Laghu-Yoga-Vāsiștha enjoyed within early modern Muslim intellectual circles.

And so, there is the "originary" samkalpa of the foundational atman/pure consciousness, which then drives its self-manifestation as the objects and entities of the phenomenal world; these objects themselves, in turn, also possess their own, individual capacities to impel further samkalpas, as the Laghu passage above informs us. Atman thus first desires/imagines on a cosmic scale-"making itself" (that is, the pure Subject) "as if" other than itself (namely, an object) - and these objects further extend ātman's originary samkalpa on a more delimited, particular, individual scale. ${ }^{37}$ In terms more appropriate to the human scale, then, it is àtman who first dreams me into existence through its samkalpa, and then I, via my own samkalpas and first-person experiences-and in constant negotiations with the manifest objects around me and my relationships of desire, attraction, aversion, categorization, memory, etc., with them-imagine my own constructed worlds within this larger world, as do each of us. To no longer fall prey to these multiple layers of delusion posed by the complex and misleading appearances of 
the phenomenal world, and by our own mistaken conceptions and constructions of them, is known as "liberation" (mokșa), which entails a certain realization of our own identity with pure consciousness, ${ }^{38}$ and which is attained, in the case of the Laghu, through the method of inquiry, self-reflection, and disciplined practice proffered by the sage Vasiștha. Indeed, the aspirant's identification with pure consciousness can even extend to the universe as a whole, itself a manifestation of the very same consciousness, as the Laghu asserts regarding the one who has attained liberation: "I-stainless, imperishable, free from passions, whose $v \bar{a} s a n a \bar{s}$ ("traces" or "impressions" ${ }^{39}$ ) are stilled-am the all-pervasive consciousness.' Having thought thus, he [the liberated one] does not grieve ... 'That which is in the tips of the grasses, in the sky, in the sun, and in people, snakes, and gods, I am that'. Having thought thus, he does not grieve anymore." 40

Despite this close overlap between their metaphysical perspectives, however, one should nevertheless resist the temptation, once again, to equate the Yoga-

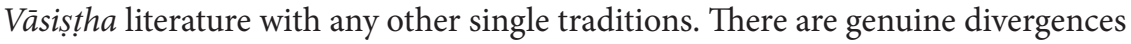
between the Laghu-Yoga-Vāsiștha and the non-dualist Saiva traditions: the latter, for instance, frequently describe pure consciousness in terms of Śiva and his feminine counterpart, Sakti, while the former, though intermittently employing terminology from a multitude of philosophical traditions, generally favors the terms preferred by Advaita Vedānta, namely, ātman and brahman. ${ }^{41}$ As Phyllis Granoff has observed, ${ }^{42}$ furthermore, despite certain (imperfect) similarities in the usage of such technical terms as spanda, Kashmir Saivism is not the only tradition to make use of these terms, while the Laghu also omits a great number of the other foundational terms of Trika thought, such as "vimarśa." 43 Indeed, Śạ̣karācārya's Advaitin predecessor, Gauḍapāda ( $8^{\text {th }}$ c. $)$ - the arguable "true founder" of the Advaita Vedānta tradition-himself employed the term "spanda" in an arguably "proto-non-dual Śaiva" way, as exemplified in the fourth chapter of his Māndūukya$k \bar{a}$ rikā. From this, some scholars have speculated that the Advaitin Gaudapāda may in fact be the source of several of the central developments in non-dualist Kashmiri thought, which could, presumably, include texts like the Mokșopāya/ Yoga-Vāsiṣtha, though the point remains disputed and insufficiently demonstrated to date. ${ }^{44}$ Whatever the truth of these speculations may be, there are certain features of the Laghu's unique metaphysics that evince a strong kinship with aspects of Advaita Vedānta, and which thus pose significant divergences from Kashmiri Saiva thought.

One such divergence occurs at the close of the passage above, where the text returns to a lexicon shared with Advaita Vedānta: in describing the apparent, phenomenal world as "neither real (satyam) nor false (mithyā)," Abhinanda arguably echoes the Advaita formulation of anirvacaniya ("inexpressible," "indescribable," or "undefinable"). The gist of this concept is that the objects of the apparent world are not truly real because they are sublated (whether by simply ceasing to be on account of their transience, or else by the dawning of the correct perception of 
reality, which, according to Advaitins, reveals brahman alone to be ultimately real); at the same time, the phenomenal world is also not purely illusory, because it is experienced in the course of everyday, conventional existence, and is thus distinguishable from a complete fiction that is never encountered in the world at all, as in the stock examples of a "hare's horn" or the "son of a barren woman" (or, in terms nearer to the Western philosophical canon, a "square circle"). The term "inexpressible" (anirvacaniya) is meant to capture this ambiguous "middle ground," that is, objects which possess a "conventional" (vyāvahārika) reality, but are neither ultimately real like brahman nor a complete and utter falsehood. ${ }^{45}$ The non-dualist Saiva traditions are not keen on this formulation, having little need for such a resort to inscrutability when, within their metaphysics, the phenomenal world is readily and fully explicable as the pulsating manifestation of pure consciousness. ${ }^{46}$ The Laghu, however, as we have seen above, alternates between affirmations of the phenomenal world as illusory in the manner of an ephemeral dream, on the one hand, and declarations of the cosmos's essential identity with pure consciousness, on the other. Within such a spectrum, an appeal to the ambiguity of anirvacaniya is befitting and effectively supports the overall perspective quite soundly, as, for Abhinanda, the phenomenal world can genuinely be said to be neither real nor unreal. Indeed, the capacious metaphysics of the Laghu allows equally well for the converse formulation, namely, that the universe is both real and unreal simultaneously, much as the wave, the drop, and the foam both are and are not the ocean at one and the same time. These formulations, once again, though drawing synthetically on the vocabulary of multiple established philosophical schools, presents a metaphysics that is peculiar to the Yoga-Vāsiștha alone.

On another point of ambiguity, we should briefly take note of an additional equivocality that accompanies the Laghu's presentation of its metaphysics and cosmology. On repeated occasions (including, partially, in the passage above), Abhinanda lays out the basic stages of his cosmogony. Starting with brahman/ätman, having harnessed its power of samkalpa, brahman effects a sequence of successively lower states and manifestations that could be considered a pared-down, reworked cosmology from the Sanskrit Sāmkhya tradition, although rejecting the puruṣaprakrti dualism of Sāmkhya in favor of its own peculiar non-dualism. Even though the Laghu varies the ordering between different passages, the overall sequence is one of brahman descending into the state of the soul (jiva), the intellect (buddhi), the "ego" or "I-sense" (ahamkāra), and the mind (manas or citta), with other, more minor manifestations sometimes enumerated thereafter, including the sense-faculties (indriyas) and/or the five elements (mahäbhütas). While ostensibly a depiction of the process of the unfolding of creation, as with many topics in the Laghu, these passages carry within them an in-built ambiguity: not only will the sequence of descents sometimes vary slightly from passage to passage, but it is also often not entirely clear if Abhinanda is describing the unfolding of the cosmos, or else the unfolding of the faculties and components of the human individual, or, perhaps, 
somehow both at the same time. As in the passage above, for instance, when we are often told that "ätman becomes manas (mind)," it remains ambiguous whether the manas being referred to is an individual human mind or else a universal cosmological entity, the "cosmic mind," so to speak, or "brahman's mind." The two commentators on the Laghu-Yoga-Vāsiștha who accompany the printed Sanskrit edition, Ātmasukha and Mummadideva, ${ }^{47}$ with whom the Jūg Bāsisht translation team was almost certainly familiar, sometimes work to iron out such ambiguities, forcing the text into one perspective or the other within a given passage. This ambiguity has additionally led to competing interpretations of the Yoga-Vāsistha, as in the Advaitin Prakāsānanda's (ca. 1500) derivation from the treatise of a thoroughgoing form of individual, subjective idealism largely unprecedented in the Advaita tradition, wherein the entirety of the phenomenal world is regarded as the creation of the individual mind/soul (manas/jīva) alone. ${ }^{48}$ Madhusūdana Sarasvatī, as will be outlined in the next chapter, endeavors to make space for both the "individual manas" and the "cosmic manas" readings, a line of exegesis that, I will argue, would go on to exert some influence over the Jüg Bāsisht translation team, to whose members we will turn presently. Before this, however, one final implication of the Laghu's metaphysical vision must be considered.

In addition to the bricolage of diverse philosophical materials and traditions that Abhinanda quietly and synthetically interweaves within his treatise, at several points throughout the Laghu, one additionally encounters the self-reflexive and explicit assertion that all of these distinct, and even competing, philosophical and theological schools are teaching one and the same truth or reality in their own ways, though utilizing their own distinctive vocabularies. I have already quoted one of these passages above: "[there is] a certain being . . . that is still, deep, neither light nor darkness, all-pervasive, unmanifest, without name. For the practical purposes of speech (vyavahārārtham), the name of that exalted self (ätman) is imagined by the wise to be 'truth/cosmic order' ( rta), 'àtman,' 'the Highest' (para), 'brahman,' 'reality' (satyam), and so forth." ${ }^{49}$ Aside from these particular terms for ultimate Reality, all of which are routinely deployed in various Hindu contexts, the Yoga-Väsiștha also extends the references into the realm of Buddhist (and even Jain and Cārvāka Materialist) thought:

This [consciousness (cit)] which eludes positive designation, and which is not within the range of words ... is what is śunnya ("emptiness") to the [Buddhist] proponents of śūnya (i.e., Madhyamaka practitioners), the most excellent brahman among the [Vedāntin] knowers of brahman (brahmavid), that which is "consciousness-only" (vijñāna-mātra) to the knowers of vijñāna (i.e., Yogācāra Buddhists), puruṣa for those who hold the Sāmkhya view, the Lord (î́sara) for the teachers of Yoga, [and] Siva for the Śaivas. ${ }^{50}$

Since the Laghu is a work of narrative "wisdom" rather than a systematic dialectical treatise, Abhinanda is never compelled to think through or work out the 
philosophical implications of statements such as these. As such, it is difficult to know what exactly to take away from Abhinanda's affirmations to this effect. On the one hand, they do lend to the Laghu a pronounced ecumenical air, of sorts, suggesting the possibility that divergent religious traditions all offer different paths to the same goal. Slaje, on the other hand, is keen to point out the various ways that the Yoga-Vâsisth ha elevates its own metaphysical view over those of other traditions, the text at one point claiming for itself the title of the "final position [encompassing the] positions of all [the other Śästras]" (or else the "final position of the final positions of all [the other Śästras]") (sarva-siddhānta-siddhānta); I would only add that this latter observation is not necessarily incompatible with the former. The notion of samkalpa once again becomes relevant in this regard, as the Yoga-Vāsiștha at numerous points suggests that the primary reason for the divergent views and terminologies of different thinkers and philosophical traditions is that they imbue their terms with "meanings based on [the limitations of] their own imagination (samkalpa)," or else, "hav[ing] not [yet] reached perfect knowledge," they "base their dispute on appearances [produced by their] own imagination (sva-vikalpa).".52

Irrespective of the limited conclusions we are able to draw from these relatively isolated statements, a few overall tendencies are clear. On the one hand, despite whatever "ecumenism" Abhinanda may or may not have intended from assertions like these, the Laghu is not an "anything goes" kind of text: it has a clear metaphysical and soteriological vision, and a distinctive, consistent notion of truth and falsehood, which somehow coexists with these affirmations of the legitimacy of other philosophical traditions and lexicons. This metaphysical perspective, as noted above, likely resonated with the wujūdi inclinations of many early modern Muslim thinkers within (and without) the Mughal court. On the other hand, the Laghu's overall sympathy for some iteration of an idea of "multiple articulations of a shared, universal truth"-even if ultimately, perhaps, a supersessionist onelikely also resonated with certain political goals and interests of the Mughal court, as exhibited in initiatives like the Mughal translation movement, to which I now direct my attention. As shall be seen in chapter 5, however, even the Laghu's inchoate ecumenism bears certain arguable complementarities with the framework for conceptualizing religious diversity that prevails within the Persian Jüg Bāsisht, and hence may well be a part of what drew Muslim interest to the Laghu-Yoga-Väsiștha in the first place.

\section{THE MUGHAL “TRANSLATION MOVEMENT” \\ AND THE LAGHU-YOGA-VĀSIST THA}

The first two emperors of the Mughal Empire in India, Bābur (r. 1526-30) and Humāyūn (r. 1530-40 and 1555-56), legitimized their rule primarily with 
reference to their noble Central Asian lineage, never making much attempt to establish local foundations for their authority. In contrast, the third emperor Akbar (r. 1556-1605) - perhaps not-so-incidentally, the first Mughal ruler to be born in South Asia-made much more extensive efforts to fashion the Mughal territory as a decidedly Indian empire, thus requiring the involvement and support of the myriad religious and ethnic groups under his rule across the diverse subcontinent. Such a policy, many have argued, was Akbar's best choice for continued governance in the midst of the overwhelmingly non-Muslim population of South Asia..$^{53}$ As part of his "inclusivistic" refashioning of the empire, while simultaneously seeking to cultivate for the Mughals the image of a relevant, cultured civilization in the eyes of the other major empires stretched across the known world, Akbar decided, in the year 1582, to abandon Chaghatāy Turkish and adopt Persian as the official administrative language of the empire. Akbar backed up this decision with lavish patronage to Persian scholarship and literature, including the translation of numerous Indian Sanskrit texts into the Persian language. Thus was begun the Mughal "translation movement," that is, the sustained effort, on the part of the Mughal court, to facilitate the Persian translation of Sanskrit texts. ${ }^{54}$

This movement is fairly well-documented in modern scholarship in its bibliographic details, though still in its infancy at the level of close textual analysis. Starting with the reign of Emperor Akbar and continuing through to the period of Prince Dārā Shikōh (d. 1659), Mughal nobles patronized and facilitated the translation of the Atharva Veda, various Upaniṣads, the Rāmāyana, the Mahäbhārata and Bhagavad-Gìtā, a number of the Purānas, and numerous other Sanskrit works into Persian. These translations were typically produced by teams of Persian-speaking Muslim courtier-scholars with the assistance of Sanskrit pandits, the two groups communicating with one another through some form of a Hindavì vernacular. One such translation, initiated at the request of Prince Salim (soon to be Emperor Jahāngīr, r. 1605-27), was the Persian rendition of the Laghu-Yoga-Vāsiștha, the "Jūg Bāsisht," completed in 1597 by the Muslim courtier Nizām al-Dīn Pānīpatī (d. 1609-10) and two Hindu Sanskrit paṇdits, Jagannātha Miśra Banārasī and Paṭhān Miśra Jājīpūrī. Subsequently, around the year 1611, the Persian-writing Iranian philosopher Mìr Findiriskī (d. 1640-41), having made several journeys to India from his homeland of Safavid Persia, began to cut-and-paste his own condensed version of the Jūg Bāsisht, entitling his abridgment the Muntakhab-i Jūg Bāsisht ("Selections from the Yoga-Vāsiștha"); Findiriskī also composed a commentary on the full text of the Jūg Bāsisht, known as the Sharh-i Jüg. Both of Findiriskīs texts will be considered in chapter 4 .

Indeed, by the sixteenth century, Yoga-Vāsiștha literature enjoyed an immense popularity across an impressive array of Hindu sectarian, geographical, and linguistic boundaries. Aside from the Mokssopāya's continued historical presence in 
Kashmir, manuscript findings demonstrate the Laghu's prevalence from India's southern tip to as far north as Delhi and Banaras, with the larger Yoga-Vāsiștha boasting a distribution that extended even further north back into the Kashmir Valley.55 Hence, from the north of Kashmir to central Maharashtra to the southern regions of Tamil Nadu, Saiva and Vaiṣnava devotees and impersonalist Advaitins alike had embraced the Yoga-Vāsiștha in varied ways, even rendering the text into several vernacular languages in the process of incorporating it into their diverse regional traditions. ${ }^{56}$ The Muslims of the medieval and early modern periods were no exception to this trend, taking interest in the treatise and translating it numerous times for their own purposes. The pre-Mughal Kashmiri sultans Zayn al-Ābidin (r. 1423-70) and Haydar Shāh (r. 1470-72), for instance, are reported to have sat in the audience of the Sanskrit litterateur Śrivara's (d. ca. 1486) recitations of the Mokṣopāya/Yoga-Vāsiștha. ${ }^{57}$ The Mughals, of course, later produced numerous Persian renditions, including, in addition to the Jūg Bāsisht (1597), another Akbar-era Laghu translation (1602) by a scholar named Farmuli, who identifies himself only as "the lowliest disciple" of the famous sant poet Kabir (d. 1518); the later translation commissioned by Prince Dārā Shikōh in the year 1656 after witnessing Vasiṣtha and Rāma in a dream; $;^{88}$ the rendition of the mysterious Shaykh Șūfī Sharīf Qubjahānī, likely based not on the Laghu, but on an even shorter Sanskrit abridgment known as the Yogavāsiștha-sāra; ${ }^{59}$ the Maharashtrian, Banaras-based Brahmin pandit of the Mughal court Kavinndrācārya Sarasvatīs Hindavī translation of the Yogavāsiṣthasāra, dated ca. 1656; 'Abd al-Raḥmān Chishtīs (d. 1683) Persian work, the "Mirror of Creation" (Mir'āt al-makhlūqāt), loosely inspired by the Yoga-Vāsiṣtha among other Sanskrit works; ${ }^{60}$ and several other Persian works based on, reworking, or inspired in some way by the Yoga-Vāsiṣtha. Fathollāh Mojtabā'ī, in his own admittedly incomplete survey of Persian manuscripts related to the Laghu, lists at least ten renditions produced at the Mughal court, not to mention the several YogaVāsiștha-related works produced independently of court patronage. ${ }^{61}$

At the very beginning stages of this chain of scholarship, thus, stands the Mughal prince Salīm, the soon-to-be-emperor Jahāngīr, whom Nizām al-Dīn Pānīpatì describes as the facilitator of this early Persian translation of the (Laghu-) Yoga-Vāsiștha:

When expert Arabic linguists, specialists in the different sciences, connoisseurs of the arts of poetry and prose, historians, and Indian pandits entered [into] the noble presence [of Prince Salīm] . . . [at that time,] the Masnavī of Mawlana Rumi, the Zafarnāmah [history of Tamerlane], the memoirs of Babur, other written histories, and collections of stories were read out in turn. Stories containing morals and advice were conveyed to the august hearing [of the prince]. In these days, the prince commanded that the book Yogavāsiștha, which contains Sufism (tașawwuf) and provides commentary on realities, diverse morals, and remarkable advice, and which is one of the famous books of the Brahmins of India, should be translated from the Sanskrit language into Persian. ${ }^{62}$ 
And so, as Ernst observes, a translation of the Laghu-Yoga-Vāsiștha was commissioned "as part of the encyclopedic collection of edifying literature initiated by Akbar." ${ }^{63}$ By the year 1597, the three commissioned translators, Nizām al-Dīn Pānīpatī, Jagannātha Miśra Banārasī, and Paṭhān Miśra Jāīipūrī, had completed their Persian translation of the entire Sanskrit treatise, some fifteen years after which Mīr Findiriskī, having migrated from Safavid Persia and spending considerable time in various parts of India, condensed this translation into his own shorter Persian rendition of the Sanskrit text, the aforementioned Muntakhab-i Jùg Bāsisht. For these and most of the translations undertaken by the Mughals, the Sanskrit source text was a version of the treatise that we could recognizably call the Laghu-Yoga-Vāsiștha, which must have been circulating through the networks and circles connected with the Mughal court at this time. Since the Persian Jūg Bāsisht is not a literal, word-for-word rendition, we cannot be certain, with philological exactitude, precisely how closely the version(s) known to the Mughals correspond with the printed edition as we know it today. In a general sense, however, we can say that, so far as can be determined through a textual comparison of the modern printed Laghu and the Persian Jūg Bäsisht, the version of the Laghu Jagannātha Miśra, Paṭhān Miśra, and Pānīpatī used appears to be in overall close accordance with the modern printed Motilal Banarsidass Laghu, as the sequences of vocabulary, teachings, and narrative tales line up quite consistently. As such, I will use the printed edition of the Laghu for my present analysis, even though we cannot rule out some variations between this edition and the translation team's copy.

Unsurprisingly, this phenomenon of Mughal translations of Sanskrit texts has long captured the attention of modern scholars. In previous decades of scholarship, one can readily discern an attraction-or revulsion, as the case may beto the notion that the pre-modern Muslims of Mughal South Asia might have exerted such great efforts to comprehend Hinduism, and thus manifested an admirably liberal, tolerant attitude toward their Hindu brethren. Anticipating the partition of South Asia into modern-day Pakistan and India, such scholars are quick to affirm, as outlined in the introduction, that two broad trajectories characterized the Mughal period: the forces of rigid Islamic orthodoxy, on the one hand, and the spirit of universal tolerance, on the other, of which the translation movement is regarded as one of the grandest expressions. We have already observed how certain more recent scholars have sought correctives for such anachronistic, nationalist histories, as witnessed, for instance, in Carl Ernst's interventions:

The political context for the Mughal interest in Sanskrit lies in the imperial program devised by Akbar and followed in varying degrees by his successors. Although earlier writers on the Mughals have treated this interest primarily as an indication of liberal personal religious inclinations on the part of Akbar, this romantic conception should yield to a more realistic analysis of policy aspects. ${ }^{64}$ 
Accordingly, current approaches to Mughal studies tend to situate the translation movement more closely within its historical, political, and social context. John Richards and Muzaffar Alam, for instance, have analyzed the Mughal interest in Sanskrit as an imperial attempt to establish local Indian credentials and legitimacy for the dynasty, on the one hand, and to develop new models of practical governance that drew on indigenous Sanskrit theories of rulership, on the other. ${ }^{65}$ For all appearances, the Mughal rulers' choice of the Laghu for translation into Persian fits very well with Richards's and Alam's analyses of the translation movement: the Laghu, besides being a popular South Asian work, also contains a great deal of commentary on the nature and qualities of the ideal king. Its translation could thus serve the double purpose of broadening the appeal of the Mughal court among indigenous Indian peoples, while also providing a rich resource for native South Asian theories of good governance.

Such interventions have provided vital correctives for how scholarship on the Mughal period has been conducted: without doubt, imperial political motives and pragmatic considerations for successful rulership in a religiously and ethnically diverse empire played centrally determinative roles within the translation movement. Yet such approaches nonetheless tend to overlook any more prevailingly philosophical motivations that may have simultaneously driven the Mughal translation enterprise. Hence, even though modern scholars have long observed that the primary resource for Persian translators rendering Sanskrit materials into Persian was the technical vocabulary of Sufism, drawing in particular from the wujūd $\bar{\imath}$ tradition associated with Ibn 'Arabi and from the corpus of classical Persian Sufi poetry ${ }^{66}$ most scholars have remained largely content with simply noting this, or else regarding it through a lens of Mughal political self-fashioning without considering the philosophical content at any great length. This study, accordingly, aims to dwell precisely on that philosophical content-without pretending, of course, that it somehow constitutes an isolated space free from the broader politics of the court.

To turn, then, to the Jüg Bāsisht and the translation team of Nizām al-Dīn Pānīpatī, Jagannātha Miśra, and Pațhān Miśra: although it would have been ideal, for the purposes of this project, to contextualize these three translators within their respective socio-political and intellectual worlds, to examine their other writings, to retrace their networks, etc., this task, alas, is thwarted by the paucity of available materials related to any one of them. Hardly anything is known about the three translators of the Jüg Bāsisht, and so our only recourse is to scrutinize their translation in an attempt to recover whatever we can about them. Aside from the general environment of the Mughal court itself, seemingly the best context one can hope to provide for the translation team is intertextual, achieved through tracing features of the Jūg Bāsisht that betray a recognizable influence or inheritance from some other known source. 


\section{THE $J \bar{U} G B \bar{A} S I S H T$ TRANSLATION TEAM}

The Muslim Persianist on the team of the Jùg Bāsisht's translators, Nizām al-Dīn Pānīpatī (d. 1609-10), is, unfortunately, not a very well-known figure. Though he garners passing mention in a few biographical compendiums (tazkirahs), these passages relate little more than his date, his translation of the Laghu, and the fact that he was employed at the Mughal court. ${ }^{67}$ We may gather from his name that his family hails from the city of Panipat (modern-day Haryana, India). Assuming that the descriptions of the ways these translations were brought about is correct-Findiriskī, for instance, says that the pandits would first translate the Sanskrit passage into a Hindavi vernacular, at which point the Persianist would render the Hindavĩ into Persian — we can guess that Pānīpatì likely did not himself know Sanskrit. Accordingly, Jagannātha Miśra and Paṭhān Miśra would have supplied an oral, Hindavi vernacular rendition of the Sanskrit Laghu, at which point Pānīpatī would presumably have taken over to supply the final Persian textual product. Knowing so little about the members of the translation team, however, one might remain open to the possibility that Pānīpatì may have had some knowledge of Sanskrit, or else, in a less improbable scenario, perhaps Jagannātha Miśra or Paṭhān Miśra possessed enough proficiency in Persian to contribute directly to the final Persian rendition of the text. Based upon a number of descriptions of the translation process, however, it seems more likely that Pānipatī was the sole direct author of the final Persian text, though produced in back-and-forth conversation with the two Sanskrit pandits, whose "fingerprints" can be carefully gleaned from the Persian text, as I will argue in subsequent chapters.

As for the first of the two Hindu Sanskrit pandits, Paṭhān Miśra Jājīpūrī, the record is similarly scant. Even his name, "Jäjippürï, which appears within the opening pages of the Jüg Bāsisht, is obscure: the most likely guess would connect him with the temple-town of Jajpur/Jajipur in modern-day Odisha-sometimes referred to as "Yajyapūra"-or else, following a variant in one of the manuscripts, his name could instead be rendered as "Jaypūrî," a possible referent to the city of Jaipur, Rajasthan (or, again, potentially, to another historical Odishan region, Jeypore).$^{68}$ The question of his ancestral geography aside, Pațhān Miśra is likely also mentioned in the Majālis-i Jahāngìrī, a record of the Mughal emperor Jahāngïr's (r. 1605-27) varied discussions with a broad spectrum of religious scholars, ranging from Hindu Brahmins and Muslim thinkers to Jewish and Jesuit intellectuals. Among these records, we find a debate between a Brahmin figure named Pațhān Miśra and a second Brahmin hailing from Gujarat regarding a particular question of Hindu dietary law and ritual impurity, with Emperor Jahāngīr on hand to witness the debate; according to Lefèvre, another figure identified as "Thayān Miśra" in Jahāngīr's memoirs (the Jahāngīr-nāmah) might also be Paṭhān Miśra. ${ }^{69}$ Such references help to establish Paṭhān Miśra's continued presence at the Mughal court 
even into the seventeenth century, as well as his possession of some of the standard knowledge expected of a Hindu Brahmin, though little more than this. While we can, again, assume that he likely did not know Persian, one can hope that future research might bring more information to light.

The second Sanskrit translator, Jagannātha Miśra Banārasī, in turn, might provide a more interesting case. Although I have not been able to find any historical references to the name "Jagannātha Miśra" other than in the Jüg Bäsisht's preface, ${ }^{70}$ another similar name, Jagannātha Paṇditarāja, echoes rather prominently throughout the historical record. Jagannātha Paṇditarāja was a Sanskrit intellectual, poet, and Hindi musician patronized by Emperor Shāh Jahān (r. 1627-58) for a variety of projects, and also, perhaps, the last scholar to compose a significant work in the classical mold of Sanskrit aesthetic theory, alamkāraśastra. ${ }^{71}$ Jagannātha Paṇịtarāja is known to have received traditional training in the discipline of Nyāya, while he also spent significant time studying with pandits in Banaras (hence, potentially, the "Banārasì" portion of his name) at a time when an elder Madhusūdana Sarasvatī might still have been resident there. ${ }^{72}$ Indeed, Jagannātha Paṇịitarāja sharply criticized Madhusūdana's contemporary and fellow Advaitin, Appayya Dikșita, on topics related to Sanskrit aesthetic theory, ${ }^{73}$ and was also personally acquainted with a number of other well-known Banaras Advaitins, including his preceptor in Sanskrit grammar (vyākarana), Vïreśvara. ${ }^{74}$ Through such acquaintances and studentships, Jagannātha Paṇditarāja, like the aforementioned courtier-pandit Kavindrācārya, could well have served as a transmitter of contemporary developments in Advaitin thought to the Mughal court. Nevertheless, given the relatively late dates of Jagannātha Paṇditarāja's wellrecorded years at the Mughal court-commencing around the year 1628-it seems unlikely that he could have been involved in a translation completed thirty-one years prior (1597). If this possibility is rejected, then, the identity of our second Sanskrit translator, Jagannātha Miśra Banārasī, will have to remain a mystery for the moment. His name can only tell us his association with Banaras, which would, again, render him a feasible channel for the transmission of the sort of Advaitin learning represented by Madhusūdana Sarasvatî into the jet streams crisscrossing the Mughal court.

Faced with this dearth of specific data and context for the translation team, we must resort to other means in order to gain analytical traction. Accordingly, this study proposes to envision the Jüg Bāsisht as a meeting-point of the Sanskrit and Arabo-Persian jet streams. As trained pandits, particularly with some connection to Advaita Vedānta-dominated Banaras, Pațhān Miśra and Jagannātha Miśra would have brought their early modern Sanskrit learning to bear upon their reading, interpretation, and translation of the Laghu-Yoga-Väsistha. In particular, as I will argue over the course of the subsequent chapters, these two Sanskrit pandits exhibit within the Jūg Bāsisht their acquaintance with particular 
debates and discussions then occurring within Sanskrit Advaitin circles, especially on the topics of $d r s ̦ t i-s r s t ̦ i-v \bar{a} d a$ ("creation-as-seeing") and eka-jīva-vāda ("doctrine of one soul") as discussed and debated by Advaitin thinkers like Madhusūdana Sarasvatī.

At the same time, the Islamic philosophical terms and concepts creatively deployed throughout the Jūg Bāsisht evince the Muslim translator Nizām al-Dīn Panipatī's scholarly learning in the Arabo-Persian world of Islamic philosophy and wujū $\bar{\imath}$ metaphysics, as represented by such Muslim thinkers as Mīr Findiriskī and Shaykh Muhibb Allāh Ilāhābādī. Even a taste from the opening passage from the Persian text of the Jüg Bāsisht may suffice to illustrate this latter point:

The Brahmins of India possess the religious path (mazhab) of the ancient sages (hukamā-i mutaqaddimin, i.e., the ancient Greek philosophers) concerning the oneness of the essence of the Real (wahdat-i zät-i haqq)-may He be praised and exalted-and concerning the qualities (sifät) of His perfection (kamāl), the levels of His descents (marätib-i tanazzulät-i $\bar{u}$ ) [into the world], the origin of multiplicity (kasrat), and the manifestation of the worlds (paydä'ì-i 'älam o 'älamìn). If any distinction (tafāvut) should obtain [between the Brahmins and the ancient sages], it would only be with respect to terminology (iștilāh $)$ and language $(z a b \bar{a} n) .^{75}$

In just this opening paragraph of the text, we encounter an abundance of technical terminology (in bold) drawn from the wujūdi tradition of philosophical Sufism; with the opening reference to the philosophers of ancient Greece-referring primarily to Plato, Aristotle, and the Neoplatonic tradition-we also see a foretaste of the Jūg Bāsisht's second main philosophical influence, namely, the tradition of Islamic Peripatetic (mashsh $\bar{a}^{\prime} \bar{\imath}$ ) philosophy. To understand what these terms might have meant to a translator like Pānīpatī, and hence to have some sense of the conceptual starting-points from which he would creatively deploy these same terms for the innovative purposes of translation, requires a deeper knowledge of the broader, contemporaneous intellectual circles in which Pānīpatī himself would have studied and participated. Accordingly, the next three chapters will reconstruct relevant slices of the Sanskrit and Arabo-Persian jet streams as instantiated in the careers and contributions of three important philosophers roughly contemporaneous with the translation of the Jūg Bāsisht, Madhusūdana Sarasvatī, Muhibb Allāh Ilāhābādī, and Mīr Findiriskī. Subsequently, we will then be able to return to passages of the sort seen here, better equipped to identify the jet stream "currents" and "wisps" that comprise the philosophical fabric of this Persian treatise.

\section{A “TASTE” OF THE PERSIAN TEXT}

Before bringing this chapter to a close and proceeding to our examination of these three philosophers, it will be useful for the reader to have a slightly fuller exposure 
to the Persian text. A small "taste" - what is called the "zawq" in Persian or the "rasa" in Sanskrit-of the character, texture, and "flavor" of the Jüg Bāsisht will provide the reader with some additional orientation for the analysis to follow. Accordingly, I translate here some additional material from the Jüg Bāsisht's opening pages. I provide only minimal annotations at this stage, as we will return to the same passage in chapter 5 , at that time better equipped to grasp its nuances. For the time being, the reader should take from this passage what she will as we dive deeper into the relevant philosophical worlds over the course of the next several chapters:

The Kashmiri pandit Abhinanda, who is the author of the text of the Yoga-Vāsistha (Jüg Bāsisht), at the commencement of this abridgment, ${ }^{76}$ leads off with the name of God and praises for the Creator (most high).

It should be known that the names (nāmhā) of the Real (most high) have no end or limit. Every one of the great $r s ̦ i s$ and the seekers of the Real (țālibān-i rāh-i haqqq) has chosen one of His names, which are in accordance with the avatāras and are the manifestations (tajallìyāt) of the levels of His self-disclosure ... Those [ $r$ șis and seekers] remember $(y \bar{a} d)$ their [chosen] name much. ${ }^{77}$ They seek, by means of that name, a generous emanation (fayz) from Him who is the origin of [all] emanation. ${ }^{78}$

The mode of the avatāra is laid out in the revered books (kutub) of the people of India. Most Indians believe that the lifetime of the world is divided into four portions (hișșah), each portion being called a "jug" (Skt., yuga). Each yuga is distinguished by its own particular qualities and features ... After the passing of the four yugas, there occurs the "pralaya" - that is, the Day of Resurrection (qiyamat) - when all the existents (mawjüdāt) of the world go to nothingness ('adam), [etc.] ...

They say that, in these four yugas, that absolute Being (hasti-i mutlaq) and Light (nür) of the unseen $(g h a y b)$, for the sake of improving the condition of the people of the world, out of its own will and generosity, manifests [itself] in the world through a special manifestation (mazhar-i khāsṣs) (i.e., an avatāra). ${ }^{79}$

As for the body of the text, I present here one of the narratives from the LaghuYoga-Vāsiștha known as the story of the bāla or "young child," hailing from the Laghu's third book, the Utpatti Prakarana. I translate the original Sanskrit version in the left column, with the corresponding Persian Jüg Bāsisht passage translated on the right. The treatise being so multi-textured, it is difficult to define, in the case of the Laghu, what would count as a "typical" or "representative" narrative: this particular tale is certainly on the shorter side, and also more comically "absurdist," I would say, than most of the Laghu's other content. This story of the young child thus humorously and memorably exemplifies the particular philosophical lesson that Vasiștha articulates to Rāma in the first portion of the chapter, while touching upon many of the themes concerning samkalpa, manas, and the world's reality/ illusion that were examined above. Again, a fuller appreciation of this Sanskrit narrative and its Persian translation must await the latter stages of this study, but a "taste" from now will help orient the reader for the chapters to come. 
Laghu-Yoga-Vāsiștha (Utpatti Prakaraṇa) (3:7:1-27; pp. 228-233)

Vasiștha said:

O Rāma, the mind (manas) of those who are wise is nothing other than that very brahman. All śaktis (potencies) are that highest brahman, imperishable (avyaya), eternal (nitya), ever-full (āpūrnna $\left.a^{80}\right)$.

Naught exists which is not within that pervading self (ätman). The self shines forth (ullasati) by means of that śakti, attaining manifestation (prakāśa).

Brahman's consciousness-śakti (cid-śakti), O Rāma, is grasped within bodies, its vibration-śakti (spandaśakti) within the wind, its strength-śakti (dārḍhyaśakti), likewise, within stone.

Its moisture-śakti within the waters, its heat-śakti, in turn, within fire; its emptiness-śakti (śūnyaśakti), likewise, in the ether (ākāśa), its destruction-śakti within [all] things perishable (vināśin).
Jūg Bāsisht (Nāīnī and Shuklā)

(Pp. 108-110)

Again Basisht (Vasiștha) said ... :

These existents (mawjūdāt) of the world ('âlam), of variegated forms (șurrat) and multifarious figures (shakl): whatever conditions ( $a$ h vāl) might befall them-whether living or dying, joy or sorrow, coming or going, good or evil-all those are forms (șürat) of the imagination (khayāl) and thought (andishah). It is only the man (manas) - that is, spiritual imagination (khayāl-i rühānī) - that has any claim over that [state of affairs] ...

O Rāmchand (Rāma)! The manas of those who have become knowing (gyānī, Sanskrit jūānin) and complete (kāmil) is barahm (brahman).

And this knowledge-śakti (gyānshakt, Sanskrit jñānaśakti) - that is, pondering (andīshah) the bodies of each individual-is from brahman. Just like the force (quwwatī) and brisk vigor (ravānī) in the wind, all that is from brahman.

The ground (zamin), which has been made flat and spread out upon the waters, and all living, animate creatures (makhlūqāt) - they all appear in and upon that [śakti], which [also] expunges them. All that is from the strength (quwwat) and power (qudrat) of brahman.

Likewise, the limpidity (safā), fluidity (ravānī), and digestive properties that exist in water $(\bar{a} b)$ are from brahman. The penetrating burning and furious annihilation (nābüd kardan) of all things that exist in fire (ātish) are from brahman. And the sūn-shakt (śūnyaśakti) also that is in the ether (ākās, Sanskrit ākāśa)which is subtle (latiif) and transcends (munazzih) all things and relations (nisbat) - is from brahman. 
Just as kuśa grass is [latent] within the water inside of the seed, in the same way, all things-possessed of [variegated] roots, sprouts, branches, flowers, vines, leaves, and fruits-are within àtman. Like the tree in the seed, this [world] abides in brahman. In any place, at any time, the śaktis arise from it (brahman), like grains of rice rising from the earth's surface, variegated in time and space.

That àtman, O Rāma, pervading all, of great, exalted, eternal, beauty-when it assumes the śakti of cogitation (manana) in even the slightest degree, then it is called "manas" (mind).

Thereafter, at first, "mind" becomes [just] the awareness (drsții) of bondage and liberation; afterwards, it becomes the array (racanā) of physical manifestation (prapañca) known as the "earth" (bhuvana). Thus, this latter state of affairs, [seemingly] possessed of enduring stability, is [really just] a tale told to a beloved boy.

\section{Blessed Rāma said:}

O best of sages, what is the children's tale that is told? Narrate to me, step-by-step, that [story] by which the [nature of] manas is explained.

\section{Vasiștha said:}

O Rāma, a certain simple-minded boy asked his nanny: $\mathrm{O}$ nanny! Tell me an amusing story.

O great-minded (Rāma), that nanny told a tale, with words sweet and serene, for the amusement of that boy.
By way of analogy (tamsill), reflect upon and understand [the following]: just as the reality (haqiqat) of a peacock (t $t \vec{a} u s)$-with its shape, figure, form, appearance, wings, feathers, blood, feet, and head-is hidden (pinhān) within the seminal water inside of its egg; in the same way, this entire world ('älam) is within brahman.

Or just as a tree-with its trunk, branches, leaves, berries, flowers, and fruits-is contained within the seed, [in the same way] this world with [all] its appearances (namūdār) is within brahman. For every person and every thing will become manifest (zāhir) in its own time (waqt) and enter into the realm of witnessing ('ālam-i shuhūd). ${ }^{81}$

"Manas" is an expression for that cogitation (andishah) of a person who is reflecting for his own sake regarding pleasure, desire, pain, ease, good, and evil-whatever occurs and appears [to him]. All that becomes manifest (payda) on account of the manas. First, there is the level (martabah) of manas; then, the level of bondage (giriftārī) and liberation (khalāṣ); and next, there is the entirety of this world (dunyā). An allegory (tamsìl) for this discussion is the tale (afsānah) which had been spoken to a boy.

At that time, Rāma entreated Vasișța:

Please speak that tale to me and explain again [the teaching]!

\section{Vasișțha began:}

There was a wishful child of little years, who requested of his nanny: "tell me a story and tale that will make my thoughts cheerful in hearing it." At that time, the nanny started speaking sweet words for the sake of occupying the boy's thoughts and delighting his heart. Of all the [choices], she began one tale, saying: 
Once upon a time, there were three princes, handsome (śubha), great-souled (mahätman), righteous (dhārmika), and rejoicing in bravery (śauryamudita), [residing] in a completely non-existent (atyantāsat) city.

Two of them were never born; moreover, the third never entered into a womb. At the same time, the handsome trio was bent on the maximum in profitable acquisition (lābha).

The three, possessed of a stainless abode, departed from their non-existent void (śūnya) of a city; traveling along, they saw trees in the firmament (gagana), laden with fruits. After stopping to rest among the sky-trees, and eating of their tasty fruit, the three princes happily and playfully departed.

Then, they reached a trio of rivers, adorned with billowing waves (kallola). Among them, one river was completely dried up (pariśușa), while the other two did not have even a little water.

After splashing around for a long time and drinking the milk-like water, they diligently bathed (snāna) in that utterly dried up river.

Then, at the end of the day, the trio reached a town that had not yet come into being (bhavisyat), wherein a circle of townsfolk was playing, hurling loud banter at each other audible from afar.

There, they then saw their three pleasing houses, one of which was completely without any walls or supports, the other two homes not yet come into being (anutpanna).
In a certain town that had no population-that is to say, it didn't exist! - there were three princes (rājankuvār, Sanskrit rājakumāra). All three were righteous ( $n \bar{i} k \bar{u} k \bar{r} r$ ), agreeable (pasandìdah), brave (dalīr), and experienced in warfare (jang-āzmā). Of these three princes, two were never born at all-that is to say, they had not been born to a mother-while the third never quickened in his mother's womb.

All three-inclining towards the acquisition (hāṣil kardan) of their desires and achieving the goal (maqș $\bar{u} d)$ harbored in their hearts-departed from that non-existent $(n \bar{a} b \bar{u} d)$ town. While on the road traveling, they saw fruit-laden trees in the ether (ākāsh). Each of the three approached those trees and plucked fruits of various sorts from them to eat, and took rest in their shade. Afterwards, the three princes left from that place.

On the way, they reached three flowing streams $(\bar{a} b-i$ ravān), each one of which had many waves (mawj). Of the three flowing streams, one was a bone-dry canal (jūy-i khushk); the remainder didn't have even a little water.

Those three princes entered that dry, waterless stream and bathed $\left(\right.$ ghus $\left.^{82}\right)$. And in that dried-up stream, like pure, white milk, they splashed around and swam for a while from one bank to the other and then back again, coming and going repeatedly, and then, having drunk the water, quenched their thirst. Then in those two streams that didn't have even a little water, they went around in circles and enjoyed the sights.

Having departed from that place, by the middle of the evening, they arrived at a town known as Bihbihkahnagar, that is to say, that which does not actually exist (bi'l-fi'l mawjūd nīst). ${ }^{83}$ They entered that town, famous (mashhür) in all corners of the world, strolling around the alleyways and circulating amongst the populace, while enjoying the views.

During the stroll, they unexpectedly spied three houses, ready to be built and decorated, in such a way that one of the houses didn't have any pillars or door or walls, while the other two weren't even buildings ('imärat) at all, there having not been any foundations (bunyād) laid whatsoever. 
Having entered their lovely abodes without any walls, those princes found a trio of pots fashioned from smelted gold.

Among the three pots, two had fallen into pieces; the other one had gone to dust. Those [princes] of shimmering intellect (śuddha-buddhi) picked up the vessel that had gone to dust.

In it, there were three measures (drona) of cooked rice, but minus three measures. Then the food was consumed by [some] Brahmins, eating copiously but who didn't have any mouths.

Then what was left from the food eaten by the Brahmins was eaten by the princes. For, they were the three princes in that town that had not yet come to be, remaining there happily, $\mathrm{O}$ child, occupying themselves with hunting deer.

Thus, O Rāma, the nanny narrated the pleasing children's tale.

That boy, possessed of an uncritical (nirvicāra) intellect $(d h \bar{h})$, was certain (niścaya) [the tale was] true. Of course, O Rāma, this children's tale was really narrated for you.

For those whose minds (cetas) have abandoned reflective inquiry (vicāra), the array (racanā) of this samsāra has attained permanence and is thus [like the case of] a children's tale.

The whole of this world (jagat) weaves a snare of samkalpa; but, from this [very same] weaving of the snare of samkalpa, the manas takes sportive pleasure (vilāsa). O Rāma, having cried out "enough with mere samkalpa!”, resorting to that which is unwavering (nirvikalpa ${ }^{84}$ ), may you attain to tranquil certitude (śāntim niścayam).
Those three entered into those non-building houses (khānah-i 'imārat nāshodah). In those houses, they found three pots which had been smelted and plaited with gold, poured into a mold, and fashioned into shape. One of them itself didn't exist (wujūd nadāsht), while another had fallen into pieces ( $p a \bar{r} c h a h$ pärchah shodah), and the other had gone to dust (zarrah zarrah gardidah).

These three princes, who didn't possess a share (bahrah) of a full intellect ('aql-i kämil) [between them], picked up the pot that had gone to dust. In that pot, they cooked three measures (durūn) of rice. It is such a quantity of rice, etc., that, having gathered rice in the palms of both hands, four of those would be called one durūn. And those three princes had three durūns minus three durūns. They distributed all that food to some Brahmins (barahmanān) who ate it. But those Brahmins ate it with utter greed, gluttony, and strange inclinations, for they were contemptible and gluttonous, each of those Brahmins not having a mouth.

Whatever was left after the Brahmins' eating, the three princes ate. Afterwards, feeling satisfied, they rested in that Bihbihkah-nagar, and passed the evening [there].

When the story reached this point, Vasișțha said to Rāma:

[With] this sort of story that the nanny told to her child, that unknowing ( nādān) child imagined (khayāl) the tale to be true (rāst). He knew it to have actually occurred, and took it as reality, not having discrimination (tamayyuz).

In the same way, O Rāma, the real condition of this [ephemeral] world (haqiqat-i hâal-i in dunyā) is also such that those of short intellect (kütah-andīshì) and absent discrimination ('adam-i tamayyuz) know something unreal (ghayr wāqi ) to be real (wāqi), and declare something not mentally constructed to be mentally constructed ( $\left.i^{\mathrm{c}} \mathrm{t} i \overline{\mathrm{a}} \mathrm{r} \bar{i}^{\mathrm{85}}\right)$. 
By way of brief commentary on this passage, at this early stage of the study, I will restrict myself to the observation, once again, of the two faces of the world's appearance on display here. On the one hand, the manifestation of the world through brahman's śakti is depicted in positive terms, as though all the majestic and delightful qualities of the cosmos are derived from brahman's own glorious attributes and potencies. On the other hand, from another perspective, this phenomenal universe is mere illusion and farce in comparison with the enduring reality of brahman, to which we should cleave instead of the world. In this latter mood, both the Sanskrit and Persian versions of the text eschew giving credit to brahman for the world's appearance, but instead attribute it to manas, imagination (samkalpa/khayal), and/or ignorance. The two slightly divergent seed analogies capture this tension rather nicely: in the first analogy, brahman is identified with the water within the seed, rather than with the seed itself. The seed-which likely stands for manas, in this instance, or else the deluding samkalpa that concludes the passage-is what possesses at least some of the latent "stuff" of the grass/field, whereas brahman is merely the quickening water situated in the heart of that seed, granting it life, motion, etc., but otherwise disengaged from the creation that ensues from it. Here, the world's appearance is construed as snare and delusion, the mood that dominates the chapter overall. In the second analogy, however, the seed itself is identified with brahman, hence reverting to the perspective where brahman's own intrinsic potencies provide the entirety of the "raw material" for this phenomenal world, construed now in more favorable terms. This doublesided metaphysics seems overall well-preserved within the Persian translation, though we will have better ability to judge towards the latter stages of the study.

One possible point of mistranslation, however, is the Persian version's tendency, in this instance, to replace the Sanskrit word atman with the term brahman. Though the Laghu certainly endorses the view that atman and brahman are ultimately non-different, the substitution nonetheless arguably transforms the passage, removing the original version's hints of a teaching tied to first-person consciousness in favor of a rendition told more straightforwardly in terms of a third-person divinity "out there." For the moment, the reader should simply bear such observations in mind, as our inquiry now shifts its focus to the three abovementioned philosophers: Madhusūdana Sarasvatī, Muhịb Allāh Ilāhābādī, and Mīr Findiriskī. 